International Journal of Child, Youth and Family Studies (2017) 8(1): 20-41

DOI: http://dx.doi.org/10.18357/ijcyfs81201716740

\title{
BAD JOBS, BAD PARENTS? HOW JOB CHARACTERISTICS RELATE TO TIME WITH CHILDREN AND SELF-EVALUATIONS OF PARENTS
}

\section{Sabrina L. Speights, Samuel J. Grubbs, and Beth A. Rubin}

\begin{abstract}
Using a data set of employed parents in the United States, the 2008 National Study of the Changing Workforce, this paper examines work characteristics, the amount of time parents spend with their children, and how parents evaluate themselves in their parenting role (their "self-evaluations as parents"). The results indicate that although work hours correlate with time spent with children, they do not correlate with parents' self-evaluations. Autonomy is critical to both parenting outcomes, even after controlling for time spent with children. Family structure is also correlated with time spent with children, but not with self-evaluations. These findings indicate that for working parents, some of the characteristics of their work influence both the amount of time spent with children and the degree to which they feel they are good parents.
\end{abstract}

Keywords: work-family, parenting, time with children, parenting evaluations

Authors' note: A previous version of this paper was presented at the 2015 Annual Meeting of the Southern Sociological Society in New Orleans, Louisiana.

Sabrina L. Speights (the corresponding author) is a doctoral student in the Organizational Science program at the University of North Carolina at Charlotte, 9201 University City Blvd, Charlotte, NC 28223. Email: sspeigh1@uncc.edu

Samuel J. Grubbs is a lecturer on Political Science at the University of North Carolina at Charlotte, 9201 University City Blvd, Charlotte, NC 28223. Email: sgrubbs@uncc.edu

Beth A. Rubin is Professor of Sociology, Public Policy, and Organizational Science at the University of North Carolina at Charlotte, 9201 University City Blvd, Charlotte, NC 28223. Email: barubin@uncc.edu 
International Journal of Child, Youth and Family Studies (2017) 8(1): 20-41

The challenge working parents experience when attempting to manage work and family is well established (Shockley \& Singla, 2011). Conflict arises because parents must negotiate multiple schedules - office hours, meetings with clients, commuting times, child care, soccer practice, school plays — that are often difficult to reconcile (Orrange, Firebaugh, \& Heck, 2003). Scholars repeatedly find that one's experience of work-family conflict is related to the nature of one’s work (Mennino, Rubin, \& Brayfield, 2005; Schieman, Milkie, \& Glavin, 2009). Few studies, however, directly examine the relationships between the characteristics of work and parenting.

In this paper, we examine the relationships between characteristics of work and two aspects of parenting: the amount of time parents spend with their children, and the degree to which respondents feel that they are good parents (what we refer to as "self-evaluations as parents"). We consider both aspects because the complex relationships between work time, family time, and parenting likely influence the time parents spend with their children and parents' self-evaluations in different ways. We argue that feeling one is doing a good job as a parent depends, at least in part, on one's occupation. In an era of “intense parenting” (Hays, 1996) in which parents often feel that they are not spending enough time with their children (Milkie, Mattingly, Nomaguchi, Bianchi, \& Robinson, 2004), the feeling of doing a good job as a parent may indicate some level of success in one's ability to perform well at work, as well as to provide one's children with physical, emotional, and cultural support. These subjective experiences are also important because it is the subjective evaluations associated with temporal experiences that are associated with key outcomes such as stress and satisfaction with work and family (Kossek \& Ozeki, 1998; Orrange et al., 2003).

The literature on work and family has long documented the constant negotiation of organizational and family obligations (Carlson, Kacmar, \& Williams, 2000; Greenhaus \& Beutell, 1985; Moen, Lam, Ammons, \& Kelly, 2013). Past research has focused on whether or not parents feel that the time they spend with their children is enough (Milkie et al., 2004), but has not considered the specific aspects of work that influence parents' ability to spend time with children.

In this study, we address this key limitation and examine the effects of work characteristics on both hours spent with children and self-evaluations as parents. By analyzing parents' selfevaluations we argue that we also capture the extent to which the management of work and family is successful. In this study, we examine the characteristics of work that are commonly associated with managing work-family conflict. Primarily, we consider autonomy, work demands, income, and scheduling. In what follows, we first consider factors that contribute to perceptions of good parenting. Second, we discuss how the nature of present-day working life can compete with societal ideals of good parenting.

\section{The Influence of Work on Perceptions of “Good” Parenting}

There is no universal definition of being a "good parent” and perceptions about good parenting have changed over time. In her examination of parental time with children, Epstein 
International Journal of Child, Youth and Family Studies (2017) 8(1): 20-41

(2004) discusses broad societal expectations of parents and how those expectations evolved. For instance, parents in the 1960s were expected to ensure their children's physical and emotional well-being. By the 1990s, parents were expected to focus far more attention on their children's future social networks and career opportunities. Hays (1996) discusses how these changing cultural expectations of increased time and attention to children act as the gauge for how "good parents" are evaluated by others and how parents view themselves. These changes in parenting expectations demonstrate why it is that although parents are spending roughly the same amount of time (or more) with their children (Sayer, Bianchi, \& Robinson, 2004), they still feel pressured and wish they had more time with their children (Milkie et al., 2004; Milkie, Kendig, Nomaguchi, \& Denny, 2010).

More recently, scholars have demonstrated that attempting to align with these expectations comes at a cost to parents (Garey, 1995; Rizzo, 2013). For instance, Henderson (2016) found that mothers who feel guilt for not meeting parenting expectations experience lower self-efficacy and higher levels of stress. Living up to cultural parenting ideologies may be particularly challenging for working parents and competing demands on time from work and children can increase depression for both mothers and fathers (Roxburgh, 2012).

In light of these cultural schemas of parenting, what Blair-Loy (2004) would call "familydevotion schemas," spending time with children becomes a difficult negotiation for working parents (especially mothers) because the demands or schedules from work tend to impinge on family time more than family time tends to impinge on work (Hecht \& Allen, 2009; Mennino et al., 2005). Given this difficult negotiation, parents alter their definitions of good parenting (Christopher, 2012). For instance, using interviews of stay-at-home, part-time, and full-time working mothers, Johnston and Swanson (2006) found profound differences among their perspectives on what it means to be a good mother, and that these correlated with the mother's employment status. Stay-at-home mothers valued being home with their children and not leaving them in the care of others. For them, a good mother was someone who could be physically present at any time of day. Working mothers, in contrast, emphasized deeper relational interactions, with greater ability to communicate and to build the child's self-esteem, as indicators of good parenting. Liss, Schiffrin, Mackintosh, Miles-McLean, \& Erchull (2013) support these findings in their study of over 500 mothers. Specifically, their results indicate that stay-at-home mothers are more likely than working mothers to perceive women as inherently better at parenting than men, and to believe that parents are primarily responsible for mentally stimulating their children.

Even among full-time employed parents, the perceptions of quality time with children can differ. From interviews with over one hundred dual-career married couples with children, Snyder (2007) found that they defined "quality time" in one of three ways. To some parents, quality time with children meant engaging in a planned activity, such as a trip to the museum, or a vacation, that was separate from the daily routine. It was only by allocating a distinct time that these parents felt able to focus solely on their families without distractions from work. For others, quality time was above all child-centered, involving impromptu, heart-to-heart talks with their children and 
being emotionally available for them. For a third group of parents, quality time included all time spent at home, even if it included friction between family members. In fact, many such parents explicitly critiqued the view of quality time as only involving positive emotions. Snyder's findings make clear the temporal component of parenting perceptions. Parents are expected to make time for their children and children's activities (Vincent \& Ball, 2007). To the extent that work constrains that time, parents may alter their definition of good parenting to emphasize quality over quantity. Even in light of these altered definitions, spending time with children reduces feelings of stress and increases satisfaction with work-family balance among parents (Milkie et al., 2010; Milkie, Raley, \& Bianchi, 2009).

Given the importance of spending time with children for maintaining healthy parent-child relationships, scholars have begun to turn their attention to examining the connections between work characteristics and both parent-child relationship quality (Roeters, van der Lippe, \& Kluwer, 2010) and parent perceptions of time adequacy (Hill, Tranby, Kelly, \& Moen, 2013). More evidence is needed, however. Examining parenting perceptions is especially important because these perceptions influence parenting competency and child outcomes (Jones \& Prinz, 2005). In the following sections, we identify specific work characteristics that are critical to managing workfamily balance. We then present hypotheses for how each characteristic relates to time with children and self-evaluations of parents.

\section{Work Characteristics and Parenting}

Most organizations take no more than a passive role in accommodating work-family conflict (Googins, 1991). In lieu of taking primary responsibility for the intense time pressures (Rubin \& Brody, 2010; Yakura, 2001) and the cultivation of overwork cultures (Collinson \& Collinson, 2004; Evans, Kunda, \& Barley, 2004) that drive much of the tension between work and family, organizational initiatives generally represent accommodating strategies that leave the onus of work-family conflict on the employee and the family. Thus, instead of examining specific policies or specific "family-friendly" organizations, we argue that the work characteristics considered in this study are a type of workplace accommodation. We suggest that work characteristics create challenges and opportunities with regard to spending time with children, and also affect parental self-evaluations. We present a review of relevant literature of work characteristics and parenting in order to consider the expected directions of specific relationships.

\section{Autonomy}

Control over one's work is arguably the job characteristic with the most influence on the relationship between work and family. Work autonomy is positively related to job satisfaction (Perrucci \& MacDermid, 2007) and is a key factor in explaining organizational commitment and engagement (Blair-Loy, 2004). Further, those with autonomy are better able to balance the disparate requirements of work and family (Schieman et al., 2009) and to manage work-family conflict (Michel, Kotrba, Mitchelson, Clark, \& Baltes, 2011). 
International Journal of Child, Youth and Family Studies (2017) 8(1): 20-41

In their analysis of a work place initiative to improve schedule control, Kelly, Moen, and Tranby (2011) found that the Results Only Work Environment (ROWE) initiative significantly reduced work-family conflict and that this effect was fully mediated by employee perceptions of schedule control. Taken together, the literature suggests that more control over work and scheduling has many positive effects on employees' individual health and work-family management. We expect autonomy to correlate both with the time spent by parents with their children, and with parents’ positive self-evaluations.

\section{Work Hours}

Historically, empirical evidence has suggested a negative impact of maternal employment on parenting quality. Much of this research takes a deprivation perspective and suggests that maternal employment detracts from child engagement and development (see Gottfried, Gottfried, \& Bathurst, 2002 for review). For example, Belsky and Eggebeen (1991) found that children were less compliant with directions at age three if their mothers had worked full time when the child was one or two years old than if their mothers had not worked outside the home at all. Using the 1986 National Longitudinal Survey of Youth, Han, Waldfogel, and Brooks-Gunn (2001) also found negative child development outcomes for White children (findings for Black children were not reported) related to maternal employment that persisted later in childhood until age 8.

The deprivation perspective, however, has come under scrutiny. First, scholars have questioned the simple assumption that increased work time necessitates a one-to-one reduction in hours spent with children (Bianchi, 2000). School-aged children, for instance, are not available to their parents for a large portion of the day, so any overlap with work hours reduces the loss of time spent with children (see Sayer et al., 2004 for review). Second, data also support the seemingly paradoxical finding that although parents (especially mothers of young children) are committing more to the labor market, the number of hours they spend with their children has changed very little (Bianchi, 2000; Bianchi, Robinson, \& Milkie, 2006). Employment can also have positive effects for the family. It may provide parents skills and resources that enrich family life and lead to enhanced home environments for children (Carlson, Hunter, Ferguson, \& Whitten, 2014; Huston \& Aronson, 2005). Finally, the effect of work hours on parenting outcomes is also influenced by indicators of social class (Augustine, 2014; Kendig \& Bianchi, 2008).

There is evidence in both positive and negative directions for the relationship between work hours and time with children and other positive child development outcomes. It is clear, however, that longer work hours lead to a greater impact on life outside work (Schieman et al., 2009) and increased work-family conflict (Byron, 2005; Michel et al., 2011). The stress and emotional guilt associated with work-family conflict (Judge, Ilies, \& Scott, 2006; Morgan \& King, 2012), is likely to reduce parental self-evaluations. 
International Journal of Child, Youth and Family Studies (2017) 8(1): 20-41

\section{Income}

Increased income is often associated with increased work commitments because increased work rewards require employees to put in extra work time. For this reason, data suggest that income correlates positively with work-home conflict (Schieman, Whitestone, \& Van Gundy, 2006) and with reductions in preferred working hours (Reynolds \& Aletraris, 2010). It is, therefore, likely that increased income also correlates with decreased time with children.

Parents with more money can, however, better afford resources and opportunities for their children. When children are young, parents with higher income can afford center care for their children while they are working (Presser, 2003). In addition to basic child-care needs, raising middle class children is an expensive endeavor (Bianchi et al., 2006), because little league, ballet lessons, and other organized activities - that have become normative (Daly, 1996) — require additional funds. Parents with higher incomes can also spend more money on vacations (Maume, 2006) and other forms of family leisure (Mattingly \& Sayer, 2006; Shaw, 1992) to enhance their children's cultural experiences. Parents with more money may use the participation of their children in these activities as a measure of good parenting because it allows time for family togetherness and decreases the stress of work-family conflict (Hilbrecht \& Smale, 2016). Taken together, although increased income may reduce time with children, parents are likely to view themselves as better parents as their income increases.

\section{Shifts and Scheduling}

The organization of work hours is another important factor. Nonstandard work schedules may reduce the time parents spend with children (Roeters et al., 2010; Wight, Raley, \& Bianchi, 2015), potentially leading to dysfunctional and hostile family dynamics that can harm children emotionally and lead to behavior problems (Strazdins, Clements, Korda, Broom, \& Souza, 2006). Child-care arrangements for those with nonstandard schedules can be complex. Scott, London, and Hurst (2005) interviewed low-income women about their child-care arrangements. These women had to find child care that could accommodate multiple jobs with working hours early in the morning and late at night. Consequently, mothers relied on family child-care homes and relatives to aid with child-care management, often needing multiple caretakers to accommodate nonstandard work schedules. Finding reliable child care was difficult. Many mothers changed caretakers often because either the care was poor or the mother's jobs or hours had changed (Hofferth \& Collins, 2000).

Parents with nonstandard schedules may experience unique child-care arrangement challenges (Presser, 1998; Henly \& Lambert, 2005); nonstandard work schedules can also increase time with children. For instance, Presser (2003) found that fathers who worked nonstandard schedules interacted with and helped their children with their homework more than did fathers working regular shifts. Interestingly, mothers' schedules did not significantly predict the frequency of one-on-one conversations with children, but nonstandard schedules did reduce the amount of time they spent with their children on activities outside the home. Overall, nonstandard shifts 
International Journal of Child, Youth and Family Studies (2017) 8(1): 20-41

complicate child-care arrangements and may interfere with the time parents can spend with their children. The uncertainty in providing care and time with children likely reduces parents' selfevaluations of their parenting quality.

\section{Methods}

\section{Data}

This study uses data from the U.S.-based 2008 National Study of the Changing Workforce (NSCW), developed by the Families and Work Institute (Bond \& Galinsky, 2008). NSCW is a representative sample derived from a phone survey of working adults in the United States. Eligibility for survey participation was contingent upon working for pay or operating a business that produced income, being 18 years of age or older, having civilian employment, and maintaining a household telephone number. Our total sample of working parents included 1,093 respondents who worked at least part time and had at least one child under 18 years old. After removing missing data, the final sample included 1,009 parents.

\section{Dependent Variables}

Time with children. To measure time spent with children, we used respondents' answers to the question: “On average, on days when you're working, about how many hours/minutes do you spend taking care of or doing things with your child/children?” We report the responses in hours.

Self-perceptions of parenting. We measure self-perceptions of parenting by using a single survey item: "On a scale of 1 to 10 - with 1 being not a good job and 10 being a very good job — how good a job do you feel you've done so far as a parent?”

\section{Independent Variables}

Work autonomy. We measured autonomy using an index of four survey items (Cronbach's $\alpha=.75$ ) on a scale from 1 (strongly disagree) to 4 (strongly agree).

- I have the freedom to decide what I do on my job.

- It is basically my own responsibility to decide how my job gets done.

- I have a lot of say about what happens on my job.

- I feel I can be myself on my job.

These questions have been previously used as a cumulative measure of work autonomy (Brody \& Rubin, 2011; Kalleberg, 2011). Furthermore, we found that these responses loaded onto one factor when we did a preliminary factor analysis. The mean response for this scale was 2.09 (Table 1).

Hours worked. Work hours includes the total number of hours the respondent worked at all jobs in a given week. 
International Journal of Child, Youth and Family Studies (2017) 8(1): 20-41

Regular schedule. Respondents were asked to indicate whether their usual work schedule or shift is a regular daytime schedule, a regular evening shift, a regular night shift, or a rotating shift. In order to compare traditional versus non-traditional schedules, we dummy-coded these responses to identify individuals who work a regular daytime schedule (coded 1) compared to all others (coded 0$)$.

Income. Income was captured by using respondent's estimates of total personal annual earnings in 2008 to measure wage level.

Hourly employee. The pay structure was dummy-coded (1=“hourly”; 0=“salaried”).

Control variables. Several family and demographic characteristics influence the ability of working parents to manage their work and parenting responsibilities. Young children who are not in school require more supervision and care than do older, school-aged children. For this reason, we include a dummy code for presence of children under the age of 6 in the model (1="yes"; $0=$ "no"). A spouse or other adult in the home will probably provide support by taking on some of the responsibility of child care. Thus, we include marital status (1=“married"; $0=$ "other”) and the number of adults in the home as controls. We also control for gender given the differences between women and men in taking on responsibility for managing the family. Life-course scholars emphasize the importance of considering the dynamism of life patterns on concepts of interest (Moen \& Sweet, 2004). In line with these arguments, we control for age because older workers may be more established in their careers. Finally, although racial differences are not typically discussed in the work-family literature, we include a dummy code for race (1="White/nonHispanic”; 0=“non-White”) because racial minorities are less likely to work in jobs that afford them the resources and income to manage their work and parenting. Further, members of racial minorities are more likely than Whites to be single parents.

\section{Analysis}

For this study, we analyzed the data using STATA 13. We used Ordinary Least Squares (OLS) regression to examine the effects of work characteristics on the time spent with children. For our analysis of perceptions of parenting, given the rank ordering of the responses, we used ordinal logistic regression. We present a table for each hypothesis examining the individual and model effects. For ease of interpretation of the coefficients, work hours reflects $1 / 10$ of the hours that each respondent worked in a given week and the income variable reflects $1 / 100,000$ of the respondents' individual estimated incomes. An examination of the data indicates that outliers and multicollinearity (determined by variance inflation factors) are not altering the results of the analysis.

\section{Results}

Table 1 includes the means, standard deviations, and correlations for all the study variables. Regarding the work variables, on average, respondents worked 43 hours per week. Approximately 
$81 \%$ of the respondents worked a regular shift schedule, and 59\% were hourly employees. The median income for the respondents was $\$ 61,123$. This figure is higher than the census data for the same year (\$52,029; Semega, 2009) because some of the respondents had extremely high incomes (16 had annual incomes above \$250,000).

Additionally, most of the respondents were married (74\%) and White (79\%). The respondents were almost evenly split between men (47\%) and women (53\%). The average respondent was 41 years old. There were 2.08 adults per household. Relatives and in-laws comprised about $66 \%$ of the non-spouse adults in the household (not shown). Thirty-nine percent of respondents had children under 6 in their home.

We also present a correlation matrix of the dependent, independent, and control variables in Table 1 . None of the correlations are stronger than \pm 0.32 , indicating that the variables are somewhat independent of each other. In particular, there is very little correlation between the two dependent variables: hours spent with children and parents' self-perceptions $(r=0.09)$. 
International Journal of Child, Youth and Family Studies (2017) 8(1): 20-41

Table 1 Parenting Variables, Work Variables, and Demographic Variables: Correlations and Descriptive Statistics (N=1,009)

\begin{tabular}{|c|c|c|c|c|c|c|c|c|c|c|c|c|c|}
\hline Variables & 1 & 2 & 3 & 4 & 5 & 6 & 7 & 8 & 9 & 10 & 11 & 12 & 13 \\
\hline 1. Self-Evaluations & - & & & & & & & & & & & & \\
\hline 2. Hours With Child & .09 & - & & & & & & & & & & & \\
\hline 3. Work Autonomy & .08 & .05 & - & & & & & & & & & & \\
\hline 4. Regular Shift" & .04 & -.05 & .10 & - & & & & & & & & & \\
\hline 5. Hourly Employee ${ }^{b}$ & .12 & .09 & -.18 & -.17 & - & & & & & & & & \\
\hline 6. Hours Worked & -.05 & -.14 & .06 & .01 & -.27 & - & & & & & & & \\
\hline 7. Income & -.01 & -.14 & .16 & .06 & -.19 & .31 & - & & & & & & \\
\hline 8. Marriedc & -.06 & -.12 & .03 & .09 & -.15 & .07 & .16 & - & & & & & \\
\hline 9. White/Non-Hispanic ${ }^{d}$ & -.15 & -.10 & .05 & .10 & -.10 & .01 & .08 & .21 & - & & & & \\
\hline 10. Female & .06 & .12 & -.06 & .02 & .11 & -.32 & -.24 & -.24 & -.10 & - & & & \\
\hline 11.Age & -.08 & -.24 & .04 & .09 & -.13 & .07 & .14 & .07 & .14 & -.04 & - & & \\
\hline 12. Adults in House & -.05 & .00 & -.04 & -.03 & .00 & .01 & .01 & .29 & -.04 & -.04 & .12 & - & \\
\hline 13. Children Under $6^{f}$ & .04 & .16 & .00 & -.05 & -.01 & .02 & -.01 & .07 & -.02 & -.14 & -.52 & -.03 & - \\
\hline M & 8.13 & 2.98 & 2.09 & .81 & .59 & 43.08 & 61122.65 & .74 & .79 & .53 & 40.83 & 2.08 & .39 \\
\hline SD & 1.29 & 2.65 & 0.74 & - & - & 11.68 & 67064.74 & - & - & - & 8.48 & 0.73 & - \\
\hline
\end{tabular}

Note. ${ }^{\mathrm{a}} 0=$ irregular shift, $1=$ regular shift. ${ }^{\mathrm{b}} \mathrm{0}=$ salaried employee, $1=$ hourly employee. ${ }^{\mathrm{c}} 0=$ not married, $1=$ married. ${ }^{\mathrm{d}} 0=$ non-White, $1=$ White/non-Hispanic. ${ }^{e} 0=$ male, $1=$ female. ${ }^{\mathrm{f}} \mathrm{O}=$ no children under age $6,1=$ presence of children under age 6 .

Standard deviations are omitted for dummy variables. 
International Journal of Child, Youth and Family Studies (2017) 8(1): 20-41

\section{Hours Spent with Children}

Table 2 presents the results of our primary analyses, testing the relationships between characteristics of parents' work situations and time spent with children. The overall model fit is statistically significant and the complete model does increase the overall variance explained. On average, parents reported spending 2.98 hours with their children on a workday (noted in Table 1); however, the median for the distribution is 2 (not presented) indicating some positive skewness in the distribution. About $10 \%$ of the respondents indicated spending more than 5 hours with their children on a workday.

Table 2 Regression Models for Work Characteristics Predicting Hours with Children

\begin{tabular}{|c|c|c|c|c|c|c|}
\hline \multirow[b]{2}{*}{ Variable } & \multicolumn{3}{|c|}{ Model 1} & \multicolumn{3}{|c|}{ Model 2} \\
\hline & $B$ & SE & t-statistic & $B$ & SE & t-statistic \\
\hline Intercept & 5.04 & 0.57 & & 5.26 & 0.76 & \\
\hline Married & -0.56 & 0.20 & $-2.82^{\star *}$ & -0.50 & 0.20 & $-2.48^{\star \star}$ \\
\hline White & -0.27 & 0.21 & -1.32 & -0.28 & 0.21 & -1.36 \\
\hline Female & 0.53 & 0.17 & $3.19 * *$ & 0.36 & 0.18 & $2.03^{\star}$ \\
\hline Age & -0.06 & 0.01 & $-5.04^{\star \star}$ & -0.05 & 0.01 & $-4.56^{\star \star}$ \\
\hline Adults in House & 0.21 & 0.12 & 1.83 & 0.20 & 0.12 & 1.78 \\
\hline Children Under 6 & 0.49 & 0.20 & $2.49 *$ & 0.50 & 0.20 & $2.57^{\star \star}$ \\
\hline Work Autonomy & & & & 0.30 & 0.11 & $2.73^{\star \star}$ \\
\hline Regular Shift & & & & -0.16 & 0.21 & -0.78 \\
\hline Hourly Employee & & & & 0.13 & 0.17 & 0.75 \\
\hline Hours Worked & & & & -0.18 & 0.08 & $-2.41^{\star \star}$ \\
\hline Income & & & & -0.24 & 0.01 & -1.86 \\
\hline $\mathrm{R}^{2}$ & 0.09 & & & 0.11 & & \\
\hline$F$ & $15.83^{\star}$ & & & $10.63^{\star}$ & & \\
\hline
\end{tabular}

${ }^{*} p<.05,{ }^{*} \mathrm{p}<.01$ 
International Journal of Child, Youth and Family Studies (2017) 8(1): 20-41

Model 1 contains only the control variables; we add the work variables in Model 2. In Model 1, as expected, there is a significant gender effect such that mothers spend more time with their children than do fathers. This effect did weaken once we accounted for the work variables, but a difference remains stable across models. Also, as expected, having young children increases the time parents spend with them. The effect of parents' age was negative, indicating that as parents get older they spend less time with their children. Surprisingly, marital status had a negative relationship with time with children: those who are married spend less time with their children than do parents who are not living with someone as a couple. This finding may be indicative of parents sharing child-care responsibilities, and each parent thus spending less time with their children. Moreover, those unpartnered parents who do not have another person with whom to share child care may of necessity spend more time with their children.

Turning to the work variables (Model 2), the positive effect of autonomy and the negative effect of work hours on time spent with children are consistent with our expectations. Interestingly, having a regular shift decreases time spent with children, and being an hourly worker increases it. Although these findings were not significant, they support the research on nonstandard schedules that suggests working parents can structure their shift work around their family demands (Clawson \& Gerstel, 2014; Fagan, 2001).

\section{Self-Evaluations as Parents}

In our second hypothesis, we evaluated respondents’ self-evaluations as parents (Table 3). The majority of the respondents rated themselves favorably on the self-evaluation scale. The mean of the distribution is 8.13 on a 10-point scale (noted in Table 1). Of the 1009 parents who responded, nearly 73\% (740) rated themselves as an 8 or higher. Furthermore, 172 (17\%) respondents graded themselves 10 out of 10 . Therefore, the results are closely grouped together.

Again, Model 1 includes only the control variables and in Model 2 we add the work variables. We find that adding work characteristics doubles the likelihood ratio chi squared, indicating a better fitting model. Finally, in Model 3, we add hours spent with children to analyze the effect of work characteristics even when accounting for the actual time spent with children. 
International Journal of Child, Youth and Family Studies (2017) 8(1): 20-41

Table 3 Regression Models for Work Characteristics Predicting Self-Evaluations as Parent

\begin{tabular}{|c|c|c|c|c|c|c|c|c|c|}
\hline \multirow[b]{2}{*}{ Variable } & \multicolumn{3}{|c|}{ Model 1} & \multicolumn{3}{|c|}{ Model 2} & \multicolumn{3}{|c|}{ Model 3} \\
\hline & $B$ & SE & $\begin{array}{c}z- \\
\text { statistic }\end{array}$ & $B$ & SE & $\begin{array}{c}z- \\
\text { statistic }\end{array}$ & $B$ & SE & $\begin{array}{c}z- \\
\text { statistic }\end{array}$ \\
\hline Married & -0.06 & 0.15 & -0.44 & -0.04 & 0.15 & -0.29 & -0.02 & 0.15 & -0.15 \\
\hline White & -0.69 & 0.15 & $-4.54^{\star *}$ & -0.71 & 0.15 & $-4.63^{\star \star}$ & -0.69 & 0.15 & $-4.51^{\star \star}$ \\
\hline Female & 0.18 & 0.12 & 1.48 & 0.15 & 0.13 & 1.16 & 0.12 & 0.13 & 0.93 \\
\hline Age & -0.01 & 0.01 & -1.08 & -0.01 & 0.01 & -0.93 & 0.00 & 0.01 & -0.55 \\
\hline Adults in House & -0.10 & 0.09 & -1.2 & -0.09 & 0.09 & -1.09 & -0.10 & 0.09 & -1.15 \\
\hline Kids Under 6 & 0.10 & 0.14 & 0.69 & 0.11 & 0.14 & 0.76 & 0.07 & 0.14 & 0.51 \\
\hline Work Autonomy & & & & 0.29 & 0.08 & $3.57^{* *}$ & 0.27 & 0.08 & $3.33^{\star *}$ \\
\hline Regular Shift & & & & 0.18 & 0.15 & 1.17 & 0.19 & 0.15 & 1.22 \\
\hline Hourly Employee & & & & 0.44 & 0.13 & $3.48 * *$ & 0.43 & 0.13 & $3.43^{\star *}$ \\
\hline Hours Worked & & & & -0.05 & 0.01 & -0.96 & -0.04 & 0.05 & -0.77 \\
\hline Income & & & & 0.08 & 0.00 & 0.94 & 0.10 & 0.01 & 1.08 \\
\hline Hours with Children & & & & & & & 0.06 & 0.03 & $2.45^{\star \star}$ \\
\hline$\chi^{2}$ & $33.93^{\star *}$ & & & $60.46^{\star *}$ & & & $66.81^{\star *}$ & & \\
\hline Log Likelihood & $82.48^{\star *}$ & & & $114.74^{*}$ & & & $120.11^{*}$ & & \\
\hline
\end{tabular}

$* \mathrm{p}<.05, * * \mathrm{p}<.01$

In agreement with our predictions, increased autonomy, working a regular shift, and increased income all positively relate to self-evaluation rankings (see Table 3, Model 2). Autonomy is, however, the only relationship that reaches statistical significance $(\mathrm{p}<.01)$. Hourly workers rank themselves higher than do salaried workers $(B=.43, p<.01)$, an effect we did not expect. Finally, in Model 3, hours spent with children had a positive effect on self-evaluations $(\mathrm{B}=.06, \mathrm{p}<.01)$. Note that autonomy and hourly pay remain significant even after accounting for the time parents report spending with their children. In contrast to the findings on time spent with children, in the self-evaluation models, the only control variable that was significant was race. Specifically, White parents rank themselves lower on their self-evaluations than do non-White parents.

\section{Discussion}

In this paper, we sought to analyze the relationships between work characteristics and both working parents' time with their children and their self-evaluations as parents. Generally, we hypothesized that work characteristics that provide parents flexibility and resources would have positive effects on time with children and self-evaluations as parents. Overall, we find some support for our hypotheses. 
International Journal of Child, Youth and Family Studies (2017) 8(1): 20-41

As demonstrated in previous research, the role of autonomy is critical for working parents (Kelly et al., 2011; Schieman et al., 2006). Parents who had more work autonomy reported spending more time with their children and provided higher self-evaluations than parents with lower levels of autonomy. This finding demonstrates that not only does autonomy provide parents with more time with their children, it also related to how they rank themselves as parents. The effect of autonomy on parenting likely occurs because when parents have discretion over their work they are able to align schedules to plan vacations, be home to talk to their children, or attend important events like plays and sports games (Snyder, 2007).

It is important also to consider the implications that work autonomy can have for parents. Control over work is viewed as a critical means for managing work and family demands because it provides employees discretion over when, where, and how their work is done (Kelly et al., 2011). Our findings demonstrate that work autonomy increases time parents spend with their children and parent self-evaluations. The relationship between autonomy and self-evaluations perhaps is evidence of positive spillover effects (Hanson \& Hammer, 2006), such that experiencing greater work autonomy leads parents to perceive that they actively guide and shape their interactions with their children. Future research should continue to examine the ways work characteristics may influence overall work-family facilitation (Wayne, Grzywacz, Carlson, \& Kacmar, 2007).

Increased hours worked, as expected, reduced the time parents spent with their children. Interestingly, work hours do not significantly predict self-evaluations (however, the relationship is negative, as predicted). Our prediction that increased work hours would result in lower selfevaluation scores was not borne out, which aligns with the literature showing that parents' employment status alters their notions of what makes a good parent (Johnston \& Swanson, 2006). Parents who work do not put as much value on their ability to be physically present with their children at all times. Instead, they value being able to support the children's aspirations and praise their accomplishments. Thus, it does after all make sense that work hours reduce the time available to spend with one's children, but that this does not translate into reduced self-evaluations as a parent.

Structure of pay was related to self-evaluations, but not in the way we expected. Hourly employees rated themselves higher than did salaried employees. We reasoned that because hourly pay is often associated with lower status work, lower income parents who are paid hourly would have lower self-evaluation scores than do parents who work for a salary. However, our findings indicate that although hourly workers report lower income and have less autonomy than salaried workers, they also work fewer hours. Hourly workers may therefore, be able to structure their schedules in ways that afford them some control over allocating time to their children (Presser, 2003). Perhaps this unexpected finding reflects class differences in the experiences at the workfamily interface such that there is a "stress of higher status" (Schieman et al., 2009) associated with salaried employees. Hourly employees, in contrast, are able to maintain the needed income to support their families but are not required to work the long hours that, as our findings 
International Journal of Child, Youth and Family Studies (2017) 8(1): 20-41

demonstrate, decrease time with children. Future research should consider class differences in how parents understand and negotiate worker and parent identities.

The effects of control variables were also of interest. In the model predicting time with children, marital status, gender, age of parent, and presence of children under the age of 6 were all significant. In contrast, the only significant control variable for self-evaluations was race, such that White parents rank themselves lower than do non-White parents. These distinct patterns of results probably arise because spending time with children has just as much to do with the characteristics of the family as with those of parent's work. Younger children need more care than older children, mothers spend more time with children than do fathers, and those who are married have another person who can spend time with the child. Thus, varied family structures affect both the ability and the need to be present for the children.

Self-evaluations, however, are specific to the parent. Mothers and fathers make assessments of themselves and these evaluations may include a multitude of factors. First, family is not always a safe haven that workers can use to escape the pressures from work (Hochschild, 1997; Clawson \& Gerstel, 2014). Families can cause stress, frustration, anger, and anxiety. This potential tension is evidenced by the studies in the work-family literature that support the bidirectionality of conflict with family as an antecedent (Carlson et al., 2000; Greenhaus \& Beutell, 1985). Additionally, there is likely social desirability bias at play (reflected in the high mean score, 8 out of 10, for the self-evaluations). Parents do not want to rank themselves low because being a parent is an important aspect of their identities, even if they also have a strong devotion to work (Blair-Loy, 2004; Moen et al., 2013). Given this restriction in the range of self-evaluation scores, our findings are likely conservative.

However, the limitations of our study must also be acknowledged. First, we relied on selfreported time estimates. Time-use scholars have long contested the accuracy of self-reported timeuse estimates because individuals do not accurately estimate the time they spend on daily tasks (Lee \& Waite, 2005). Although we cannot escape this limitation, we feel that the contextualized question asking how much time parents spend with their children on days they are working is an advantage that helps to limit the scope of recall for respondents. Future research should incorporate additional forms of data, such as experiential sampling methods, to better capture the time parents spend with their children.

Second, we were unable to analyze the complexity of family life. Potential tensions at home may weigh more heavily in parents' evaluations and have implications for the time parents want to spend with their children. Future research should capture data on perceptions of family life and even include information from spouses and children in their analyses.

Finally, although nationally representative of the United States, the NSCW produces a rather homogenous group of working parents and can only speak to the values of one country. The majority of the respondents were White and had relatively high incomes; the sample, therefore, 
does not capture the experiences of a vast number who live in the United States. Although the NSCW is a valuable source of data on workplace perceptions, the unique and complex relationships between race, class, and work in the United States cannot be properly assessed with this data set. An important next step in assessing the connections between the nature of work and parenting is broadening the diversity of types of work and the demographics of the parents in the analysis.

Despite these limitations, the current analysis finds that the nature of work does have implications not only on time spent with children, but on self-evaluations of parents. Presently there are very few family-friendly federal workplace policies in the United States that encourage parents to spend time with children (an exception is the 12 weeks of unpaid leave provided by the Family and Medical Leave Act of 1993). We view this study as an important step towards understanding the connection between work and perceptions of success in work-family management.

\section{Conclusion}

The time it takes to raise a child is central to discussions of rising work demands. However, few studies examine the efficacy of strategies used to manage work and family. Our investigation addresses this limitation by examining both time spent with children and how parents rate themselves (self-evaluations). Our findings support much of the work-family literature that suggests control over work and increased work demands have critical implications for the ability of working parents to balance the needs of work and family. We extend previous research by highlighting that the evaluation of the efficacy of strategies to manage work and family is critical to understanding and improving the quality of life of contemporary working parents. 
International Journal of Child, Youth and Family Studies (2017) 8(1): 20-41

\section{References}

Augustine, J. M. (2014). Mothers' employment, education, and parenting. Work and Occupations, 41(2), 237-270. doi:10.1177/0730888413501342

Belsky, J., \& Eggebeen, D. (1991). Early and extensive maternal employment and young children's socioemotional development: Children of the National Longitudinal Survey of Youth. Journal of Marriage and the Family, 53(4), 1083-1110. doi:10.2307/353011

Bianchi, S. M. (2000). Maternal employment and time with children: Dramatic change or surprising continuity? Demography, 37(4), 401-414. doi:10.1353/dem.2000.0001

Bianchi, S. M., Robinson, J. P., \& Milkie, M. A. (2006). Changing rhythms of American family life. New York, NY: Russell Sage Foundation.

Blair-Loy, M. (2004). Work devotion and work time. In C. F. Epstein \& A. Kalleberg (Eds.), Fighting for time: Shifting boundaries of work and social life (pp. 282-316). New York, NY: Russell Sage Foundation.

Bond, J., \& Galinsky, E. (2008). The 2008 national study of the changing workforce. New York, NY: Families and Work Institute.

Brody, C. J., \& Rubin, B. A. (2011). Generational differences in the effects of insecurity, restructured workplace temporalities, and technology on organizational loyalty. Sociological Spectrum, 31(2), 163-192. doi:10.1080/02732173.2011.541341

Byron, K. (2005). A meta-analytic review of work-family conflict and its antecedents. Journal of Vocational Behavior, 67, 169-198. doi:10.1016/j.jvb.2004.08.009

Carlson, D. S., Hunter, E. M., Ferguson, M., \& Whitten, D. (2014). Work-family enrichment and satisfaction : Mediating processes and relative impact of originating and receiving domains. Journal of Management, 40(3), 845-865. doi:10.1177/0149206311414429

Carlson, D. S., Kacmar, K. M., \& Williams, L. J. (2000). Construction and initial validation of a multidimensional measure of work-family conflict. Journal of Vocational Behavior, 56(2), 249-276. doi:10.1006/jvbe.1999.1713

Christopher, K. (2012). Extensive mothering: Employed mothers' constructions of the good mother. Gender \& Society, 26(1), 73-96.

Clawson, D., \& Gerstel, N. (2014). Unequal time: Gender, class, and family in employment schedules. New York, NY: Russell Sage Foundation. 
International Journal of Child, Youth and Family Studies (2017) 8(1): 20-41

Collinson, D. L., \& Collinson, M. (2004). The power of time: Leadership, management, and gender. In C. Epstein \& A. Kalleberg (Eds.), Fighting for time: Shifting boundaries of work and social life (pp. 219-246). New York, NY: Russell Sage Foundation.

Daly, K. (1996). Time together: The social construction of family time. In B. N. Adams \& D. M. Klein (Eds.), Families and time: Keeping pace in a hurried culture (pp. 66-84). Thousand Oaks, CA: Sage.

Epstein, C. F. (2004). Border crossings: The constraints of time norms in transgressions of gender and professional roles. In C. F. Epstein \& A. Kalleberg (Eds.), Fighting for time: Shifting boundaries of work and social life (pp. 317-340). New York, NY: Russell Sage Foundation.

Evans, J. A., Kunda, G., \& Barley, S. R. (2004). Beach time, bridge time, and billable hours: The temporal structure of technical contracting. Administrative Science Quarterly, 49(1), 1-38.

Fagan, C. (2001). The temporal reorganization of employment and the household rhythm of work schedules: The implications for gender and class relations. American Behavioral Scientist, 44(7), 1199-1212. doi:10.1177/00027640121956728

Garey, A. I. (1995). Constructing motherhood on the night shift: "Working mothers" as "stay-athome moms.” Qualitative Sociology, 18(4), 415-437. doi:10.1007/BF02404489

Googins, B. K. (1991). Work/family conflicts: Private lives-public responses. New York, NY: Auburn House.

Gottfried, A. E., Gottfried, A. W., \& Bathurst, K. (2002). Maternal and dual-earner employment status and parenting. In M. H. Bornstein (Ed.), The handbook of parenting (Volume 2): Biology and ecology of parenting (pp. 207-230). Mahwah, NJ: Lawrence Erlbaum Associates.

Greenhaus, J. H., \& Beutell, N. J. (1985). Sources of conflict between work and family roles. Academy of Management Review, 10(1), 76-88. doi:10.5465/AMR.1985.4277352

Han, W. J., Waldfogel, J., \& Brooks-Gunn, J. (2001). The effects of early maternal employment on later cognitive and behavioral outcomes. Journal of Marriage and the Family, 63(2), 336-354. doi:10.1111/j.1741-3737.2001.00336.x

Hanson, G. C., \& Hammer, L. B. (2006). Development and validation of a multidimensional scale of perceived work-family positive spillover. Journal of Occupational Health Psychology, 11(3), 249-265.

Hays, S. (1996). The cultural contradictions of motherhood. New Haven, CT: Yale University Press. 
International Journal of Child, Youth and Family Studies (2017) 8(1): 20-41

Hecht, T. D., \& Allen, N. J. (2009). A longitudinal examination of the work-nonwork boundary strength construct. Journal of Organizational Behavior, 30(7), 839-862. doi:10.1002/job.579

Henly, J. R., \& Lambert, S. (2005). Nonstandard work and child-care needs of low-income parents. In S. M. Bianchi, L. M. Casper, \& B. R. King (Eds.), Work, family, health, and well-being (pp. 473-492). Mahwah, NJ: Lawrence Erlbaum Associates.

Hilbrecht, M., \& Smale, B. (2016). The contribution of paid vacation time to wellbeing among employed Canadians. Leisure/Loisir, 40(1), 31-54.

Hill, R., Tranby, E., Kelly, E. L., \& Moen, P. (2013). Relieving the time squeeze? Effects of a white-collar workplace change on parents. Journal of Marriage and Family, 75, 10141029. doi:10.1111/jomf.12047

Hochschild, A. R. (1997). The time bind: When home becomes work and work becomes home. New York, NY: Metropolitan Books.

Hofferth, S., \& Collins, N. (2000). Child care and employment turnover. Population Research and Policy Review, 19(4), 357-395. doi:10.1023/A:1026575709022

Huston, A. C., \& Aronson, S. R. (2005). Mothers' time with infant and time in employment as predictors of mother-child relationships and children's early development. Development, 76(2), 467-482. doi:10.1111/j.1467-8624.2005.00857.x

Johnston, D. D., \& Swanson, D. H. (2006). Constructing the "good mother": The experience of mothering ideologies by work status. Sex Roles, 54, 509-519. doi:10.1007/s11199-0069021-3

Jones, T. L., \& Prinz, R. J. (2005). Potential roles of parental self-efficacy in parent and child adjustment : A review. Clinical Psychology Review, 25, 341-363. doi:10.1016/j.cpr.2004.12.004

Judge, T. A., Ilies, R., \& Scott, B. (2006). Work-family conflict and emotions: Effects at work and at home. Personnel Psychology, 59, 779-814. doi:10.1111/j.1744-6570.2006.00054.x

Kalleberg, A. L. (2011). Good jobs, bad jobs: The rise of polarized and precarious employment systems in the United States, 1970s to 2000s. New York, NY: Russell Sage Foundation.

Kelly, E. L., Moen, P., \& Tranby, E. (2011). Changing workplaces to reduce work-family conflict: Schedule control in a white-collar organization. American Sociological Review, 76(2), 265-290. doi:10.1177/0003122411400056 
International Journal of Child, Youth and Family Studies (2017) 8(1): 20-41

Kendig, S. M., \& Bianchi, S. M. (2008). Single, cohabitating, and married mothers' time with children. Journal of Marriage and Family, 70(5), 1228-1240. doi:10.1111/j.17413737.2008.00562.x

Kossek, E. E., \& Ozeki, C. (1998). Work-family conflict, policies, and the job-life satisfaction relationship: A review and directions for organizational behavior-human resources research. Journal of Applied Psychology, 83(2), 139-149. doi:10.1037/0021-9010.83.2.139

Lee, Y., \& Waite, L. J. (2005). Husbands' and wives' time spent on housework: A comparison of measures. Journal of Marriage and Family, 67(2), 328-336.

Liss, M., Schiffrin, H. H., Mackintosh, V. H., Miles-McLean, H., \& Erchull, M. J. (2013). Development and validation of a quantitative measure of intensive parenting attitudes. Journal of Child and Family Studies, 22(5), 621-636. doi:10.1007/s10826-012-9616-y

Mattingly, M. J., \& Sayer, L. C. (2006). Under pressure: Gender differences in the relationship between free time and feeling rushed. Journal of Marriage and Family, 68(1), 205-221. doi:10.1111/j.1741-3737.2006.00242.x

Maume, D. J. (2006). Gender differences in taking vacation time. Work and Occupations, 33(2), 161-190. doi:10.1177/0730888405284568

Mennino, S. F., Rubin, B. A., \& Brayfield, A. (2005). Home-to-job and job-to-home spillover: The impact of company policies and workplace culture. Sociological Quarterly, 46(1), 107135. doi:10.1111/j.1533-8525.2005.00006.x

Michel, J. S., Kotrba, L. M., Mitchelson, J. K., Clark, M. A., \& Baltes, B. B. (2011). Antecedents of work-family conflict: A meta-analytic review. Journal of Organizational Behavior, 32, 689-725. doi:10.1002/job.695

Milkie, M. A., Kendig, S. M., Nomaguchi, K. M., \& Denny, K. E. (2010). Time with children, children's well-being, and work-family balance among employed parents. Journal of Marriage and Family, 72, 1329-1343. doi:10.1111/j.1741-3737.2010.00768.x

Milkie, M. A., Mattingly, M. J., Nomaguchi, K. M., Bianchi, S. M., \& Robinson, J. P. (2004). The time squeeze: Parental statuses and feelings about time with children. Journal of Marriage and Family, 66(3), 739-761. doi:10.1111/j.0022-2445.2004.00050.x

Milkie, M. A., Raley, S. B., \& Bianchi, S. M. (2009). Taking on the second shift: Time allocations and time pressures of U.S. parents with preschoolers. Social Forces, 88(2), 487517.

Moen, P., Lam, J., Ammons, S. K., \& Kelly, E. L. (2013). Time work by overworked professionals: Strategies in response to the stress of higher status. Work and Occupations, 40(2), 79-114. doi:10.1177/0730888413481482 
International Journal of Child, Youth and Family Studies (2017) 8(1): 20-41

Moen, P., \& Sweet, S. (2004). From "work-family" to "flexible careers": A life course reframing. Community, Work \& Family, 7(2), 209-226.

doi:10.1080/1366880042000245489

Morgan, W. B., \& King, E. B. (2012). The association between work-family guilt and pro- and anti-social work behavior. Journal of Social Issues, 68(4), 684-703. doi:10.1111/j.15404560.2012.01771.x

Orrange, R. M., Firebaugh, F. M., \& Heck, R. K. Z. (2003). Managing households. In P. Moen (Ed.), It’s about time: Couples and careers (pp. 153-167). New York, NY: ILR Press.

Perrucci, R., \& MacDermid, S. (2007). Time and control in a 24/7 environment: Clock time, work time, family time. In B. A. Rubin (Ed.), Workplace temporalities: Research in the sociology of work (pp. 343-368). Oxford, UK: JAI Press.

Presser, H. B. (1998). Shift work and child care among young dual-earner American parents. Journal of Marriage and Family, 50(1), 133-148. doi:10.2307/352434

Presser, H. B. (2003). Working in the 24/7 economy: Challenges for American families. New York, NY: Russell Sage Foundation.

Reynolds, J., \& Aletraris, L. (2010). Mostly mismatched with a chance of settling: Tracking work hour mismatches in the United States. Work and Occupations, 37(4), 476-511. doi:10.1177/0730888410383245

Roeters, A., van der Lippe, T., \& Kluwer, E. S. (2010). Work characteristics and parent-child relationship quality: The mediating role of temporal involvement. Journal of Marriage and Family, 72, 1317-1328. doi:10.1111/j.1741-3737.2010.00767.x

Roxburgh, S. (2012). Parental time pressures and depression among married dual-earner parents. Journal of Family Issues, 33(8), 1027-1053. doi:10.1177/0192513X11425324

Rubin, B. A., \& Brody, C. J. (2010). Age differences in the consequences of feeling overworked. In J. B. Davies (Ed.), Global Social Economy (pp. 97-114). London, UK: Routledge.

Sayer, L. C. (2005). Gender, time and inequality: Trends in women’s and men's paid work, unpaid work and free time. Social Forces, 84(1), 285-303. doi:10.1353/sof.2005.0126

Sayer, L. C., Bianchi, S. M., \& Robinson, J. P. (2004). Are parents investing less in children? Trends in mothers' and fathers' time with children. American Journal of Sociology, 110(1), 1-43. doi:10.1086/386270

Schieman, S., Milkie, M., \& Glavin, P. (2009). When work interferes with life: Work-nonwork interference and the influence of demands and resources. American Sociological Review, 74(6), 966-988. doi:10.1177/000312240907400606 
International Journal of Child, Youth and Family Studies (2017) 8(1): 20-41

Schieman, S., Whitestone, Y. K., \& Van Gundy, K. (2006). The nature of work and the stress of higher status. Journal of Health and Social Behavior, 47(3), 242-57. doi:10.1177/002214650604700304

Scott, E. K., London, A. S., \& Hurst, A. (2005). Instability in patchworks of child care when moving from welfare to work. Journal of Marriage and Family, 67(2), 370-386. doi:10.1111/j.0022-2445.2005.00122.x

Semega, J. (2009). Median household income for states: 2007 and 2008 American community surveys (American Community Survey Reports). U.S. Census Bureau. Retrieved from https://www.census.gov/prod/2009pubs/acsbr08-2.pdf

Shaw, S. (1992). Dereifying family leisure: An examination of women's and mens everyday experiences and preceptions of family time. Leisure Sciences, 14, 271-286.

Shockley, K. M., \& Singla, N. (2011). Reconsidering work-family interactions and satisfaction: A meta-analysis. Journal of Management, 37(3), 861-886. doi:10.1177/0149206310394864

Snyder, K. A. (2007). A vocabulary of motives : Understanding how parents define quality time. Journal of Marriage and Family, 69, 320-340.

Strazdins, L., Clements, M. S., Korda, R. J., Broom, D. H., \& Souza, R. M. D. (2006). Unsociable work? Nonstandard work schedules, family relationships, and children's wellbeing. Journal of Marriage and Family, 68(2), 394-410.

Vincent, C., \& Ball, S. J. (2007). “Making up” the middle-class child: Families, activities and class dispositions. Sociology, 41(6), 1061-1077. doi:10.1177/0038038507082315

Wayne, J. H., Grzywacz, J. G., Carlson, D. S., \& Kacmar, K. M. (2007). Work-family facilitation: A theoretical explanation and model of primary antecedents and consequences. Human Resource Management Review, 17(1), 63-76.

Wight, V. R., Raley, S. B., \& Bianchi, S. M. (2015). Time for children, one’s spouse and oneself among parents who work nonstandard hours. Social Forces, 87(1), 243-271.

Yakura, E. K. (2001). Billables: The valorization of time in consulting. American Behavioral Scientist, 44(7),1076-1095. 